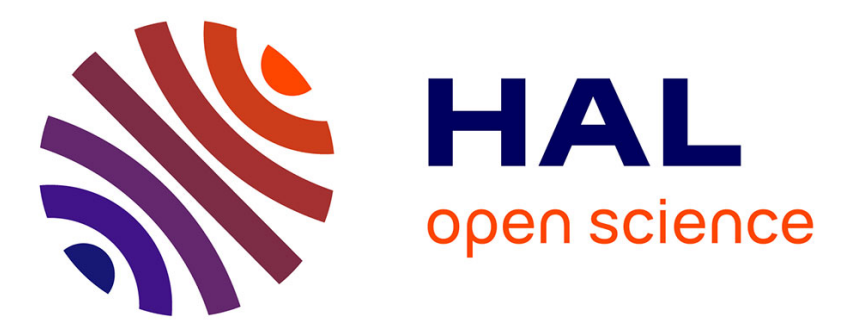

\title{
From sketches to publication: the genesis of the Essai d'une carte géologique by Omalius d'Halloy and Coquebert de Montbret (1810-1823)
}

Isabelle Laboulais

\section{- To cite this version: \\ Isabelle Laboulais. From sketches to publication: the genesis of the Essai d'une carte géologique by Omalius d'Halloy and Coquebert de Montbret (1810-1823). Earth Sciences History. Journal of the History of the Earth Sciences Society, 2007, 26 (1), pp.31-53. hal-02932788}

\section{HAL Id: hal-02932788 \\ https://hal.science/hal-02932788}

Submitted on 7 Sep 2020

HAL is a multi-disciplinary open access archive for the deposit and dissemination of scientific research documents, whether they are published or not. The documents may come from teaching and research institutions in France or abroad, or from public or private research centers.
L'archive ouverte pluridisciplinaire HAL, est destinée au dépôt et à la diffusion de documents scientifiques de niveau recherche, publiés ou non, émanant des établissements d'enseignement et de recherche français ou étrangers, des laboratoires publics ou privés. 


\title{
From sketches to publication : the genesis of the Essai d'une carte géologique by Omalius d'Halloy and Coquebert de Montbret (1810-1823)
}

\author{
Isabelle Laboulais (Université Marc Bloch - Strasbourg 2)
}

In December 1822, the Essai d'une carte géologique de la France, des Pays-Bas et de quelques contrées voisines dressée par J.-J. d'Omalius d'Halloy d'après des matériaux recueillis de concert avec Mr. le baron Coquebert de Montbret ${ }^{1}$ left the workshop of the Parisian engraver Berthe. ${ }^{2}$ While it is probably an exaggeration to say that this map was awaited in academic circles, its appearance had nevertheless been widely announced by the two collaborators, who multiplied initiatives to make their work known even before its publication. As early as February 19, 1821, Charles-Etienne Coquebert de Montbret (17551831) presented a memoir to the Académie des sciences in which he used a draft of that map to observe "the influence exerted by the general nature of the terrain on several kinds of culture". ${ }^{3}$ On September 9, 1822, he then presented to his colleagues of that same academy a report on Omalius d'Halloy's "Carte minéralogique de la France". ${ }^{4}$ This young Belgian scholar (1783-1875) had also published in 1822 his "Observations sur un essai de carte géologique" in the Annales des mines, ${ }^{5}$ a text he submitted as well to the Académie royale of Belgium. ${ }^{6}$ Before the map was printed, and even before its title was definitely fixed, it was thus already known by a number of the actors of the scholarly community. The activity deployed by Omalius d'Halloy and Coquebert de Montbret in 1823 only whetted scholarly expectations: Omalius d'Halloy's Observations sur un essai de carte géologique were published in a separate instalment, printed at Veuve Huzard's and sold with the map, while

\footnotetext{
${ }^{1}$ Montbret carte 335 (1): Essai d'une carte géologique de la France, des Pays-Bas et de quelques contrées voisines dressée par J.J. d'Omalius d'Halloy d'après des matériaux recueillis de concert avec Mr. le baron Coquebert de Montbret, engraved by Berthe, Paris, 1823, 1: 3700 00. A digital version of the maps mentioned in this article can be consulted on the following site: http://misha1.u-strasbg.fr/cdm/ ; the originals are all kept in the Bibliothèque municipale of Rouen.

${ }^{2}$ The same year, L. Berthe also engraved a Nouvelle carte politique et routière de l'Europe où se trouvent tracés les... Etats Souverains (1:6 250 000), as well as a Carte intitulée Espagne et Portugal dressée par Lapie (about 1:1985 000).

${ }^{3}$ Archives de l'Académie des sciences, Pochette de la séance du 19 février 1821, "Note relative à une ébauche de carte minéralogique de la France sur laquelle ont été tracées les limites géographiques de la culture des vignes, des oliviers, des orangers, présentée à l'académie des sciences par M. Coquebert de Montbret, membre de cette compagnie", and Procès-verbaux des séances de l'Académie tenues depuis la fondation de l'Institut jusqu'au mois d'août 1835, vol. 7, page 147.

${ }^{4}$ Ibid.

${ }^{5}$ Annales des mines, vol. 7, 1822, p. 353-376.

${ }^{6}$ Archives de l'Académie royale de Belgique, $\mathrm{n}^{\circ}$ 4829. This file contains a handwritten version of the "Observations sur un essai de carte géologique", as well as an accompanying letter written by Omalius d'Halloy, dated September 30, 1822.
} 
Coquebert de Montbret presented the printed map to his colleagues of the Sociéte de géographie on February 7, $1823 .^{7}$

If this map thus attracted the attention of both scholars and administrators, it is probably because it appeared at a time when reflections on geological map production and their use were widespread. In 1822 the Ministry of Public Works adopted the project proposed by the Ecole des Mines, of making a geological map of France on a scale of 1: 500 000. This project was not new, but had been elaborated as early as 1811 by André Brochant du Villiers, professor of mineralogy and geology at the Ecole des Mines, at the very moment when Omalius d'Halloy was in charge of gathering the materials for a geological description of the French Empire. He worked on this project until 1814, when he wrote his « Observations sur un essai de carte géologique », before taking up an administrative career and becoming governor of the province of Namur. The manuscript map he drew at the end of his travels was then only known by a few Parisian geologists - a copy had, for example, been entrusted to Alexandre Brongniart, another one deposited at the Ecole des mines ${ }^{8}$-, and it was only at the beginning of the 1820s that Coquebert de Montbret took steps to publish that map, in the hope of turning it into a working tool for the use of the entire scholarly community. ${ }^{9}$

While the Essai d'une carte géologique published in 1822 has not had the posterity its authors had hoped for, its history nevertheless deserves a closer look. Although its scale (about 1: 3700 000), and the technique used for making it (the map was colored by hand at a time when the first geological maps printed in colour were appearing) make it a map of the past, ${ }^{10}$ it nevertheless testifies to the experiments and even cartographic tinkerings that were conceived in the 1810s by conciliating the expectations of the administration and those of science. Moreover, it offers a good example of the conditions of map production at that time. Without postulating that the appearance of that Essai constituted a critical step in the history of cartography, this article examines the different episodes which led to its publication, by considering first the investigative methods, then the different stages of map construction, and finally the uncertainties surrounding its publication, in order to grasp the stakes of such an

\footnotetext{
${ }^{7}$ Bulletin de la Société de géographie, volume 1, page 172, Meeting of February 7, 1823.

8 "Several persons have complained that our work had had no other advertisement than being deposited at the Ecole des Mines and in the study of M. Brongniart.", Archives de l'Académie royale de Belgique, $\mathrm{n}^{\circ} 8864$, Scientific correspondence of J.J. Omalius d'Halloy, Letter from Charles-Etienne Coquebert de Montbret to J.J. Omalius d'Halloy, December 13, 1821, fol. 268-271.

9 Laboulais (Isabelle), "Reading a vision of space: The geographical map collection of Charles-Etienne Coquebert de Montbret (1755-1831)", Imago Mundi, volume 56, Part 1, January 2004, p. 48-66.

${ }^{10}$ On these questions, see Cook (Karen Severud), "From False Starts to Firm Beginnings: Early Colour Printing of Geological Maps", Imago Mundi, n 47, 1995, p. 155-172, and Savaton (Pierre), "Evolution des cartes géologiques de la France depuis le début du XIXe siècle”, Géologie de la France, 1999, n 2, 1999, p. 65-78.
} 
enterprise, at the moment when reflections on the making of a geological map of France were developing, ${ }^{11}$ in particular at the Ecole des mines ${ }^{12}$.

\section{The investigation}

The field work which preceded the making of this map clearly anchors the cartographic enterprise on the side of a statistical tradition preoccupied with the identification and localization of resources. In 1810, when Omalius d'Halloy was appointed second lieutenant by imperial order and was given the responsibility of gathering materials for a geological description of the French Empire, his mission consisted in surveying the natural resources as a whole and in drawing the correlations which could be found between the nature of the terrain and agricultural production. Administrative expectations defined the goals and no scientific presuppositions were suggested. At the time of this appointment, Coquebert de Montbret ran the Statistics Bureau at the Ministry of the Interior, and thus Omalius d'Halloy joined his collaborators. ${ }^{13}$ In 1823 , at the beginning of his Observations sur un essai de carte géologique, he evoked the setting in which he had worked, as well as the nature of his collaboration with Coquebert de Montbret :

"During Mr. the baron Coquebert de Montbret's direction of the statistics bureau of France, he conceived the project of a general description of this vast state, to be established on a basis less varying than political or administrative divisions, avoiding the repetitions always entailed by specific descriptions of each of these artificial divisions; he wanted, in consequence, to base his work on a division along physical regions; but he felt that hydrographic basins, although invariable in truth, were no more fecund in general results than political circumscriptions; he thought, on the contrary, that the only divisions suited to the aim he had in view were those determined by the nature of the terrain. A country's production is indeed dependant upon this circumstance, and despite the modifications that can be brought about by the mores, the governments and other accessories, inhabitants are in general ever dependant on the production of their soil.,"14

\footnotetext{
${ }^{11}$ As early as 1987, Josef Konwitz drew attention to the mysterious history of that map. In his book, he described the complex archival journey he had to undertake - from the Département des Cartes et plans at the Bibliothèque nationale de France, to the Archives de l'Académie royale de Belgique, via those of the Académie des sciences - to identify the map. He missed one collection however : that held in the Bibliothèque municipale of Rouen. Cf. Konvitz (Josef), Cartography in France 1660-1848. Science, engineering and statecraft, Chicago, The University of Chicago Press, 1987, p. 301-304.

12 "The Commission of the Annales des mines has told me about your offer of your 'essai de carte géologique de la France'. I am highly sensitive to this offer, and I appreciate the usefulness of your work; it sets the basis of the research I have ordered and which are being dealt with on the geology of the Kingdom. I can only thank you for having communicated them." Archives de l'Académie royale de Belgique, ${ }^{\circ} 8864$, Scientific correspondence of J.J. Omalius d'Halloy, Letter from Becquey to J.J. Omalius d'Halloy, October 5, 1822, fol 492.

${ }^{13}$ Gillispie (Charles Coulston), "Omalius d'Halloy", Dictionary of Scientific Biography, vol. X, New York, Charles Scribner's Sons, 1974, p. 208-210.

${ }^{14}$ Omalius d'Halloy (Jean-Baptiste Julien d'), Observations sur un essai de carte géologique de la France, des Pays-Bas et des contrées voisines, Paris, Madame Huzard, 1823 [offprint from the Annales des mines, 1822], p. 3-4.
} 
Despite the convergence of view between the two men on the necessity of identifying physical regions, their official collaboration was short-lived for, just as Omalius d'Halloy's appointment became effective, Coquebert de Montbret was appointed head of the customs administration in Amsterdam. In spite of this change of posting, the latter was so convinced by the usefulness of Omalius d'Halloy's enterprise that he continued to follow the work of the young geologist who, between 1810 and 1812, multiplied journeys of investigation during which he collected data for statistical use. In 1810, Omalius d'Halloy sharpened his knowledge of northern France by travelling through the land of Bray; in 1811 he discovered the centre of France, before going to Italy in $1812 .{ }^{15}$ The shared concern to identify physical regions thus took shape in a governmental context but eventually materialized in the private setting of scholarly sociability. Indeed, when Omalius d'Halloy's mission came to an end, it no longer responded to a work commissioned by the administration. The production of the ensuing map thus provides a good example of the impact of administrative practices on the development of scientific interrogations, and enables us to compare how a geologist and an administrator looked at nature. ${ }^{16}$

The archives of the Belgian Royal Academy reveal the method Omalius d'Halloy perfected to organise his travel notes. Four different types of material are conserved, each clearly corresponding to a stage in the elaboration of knowledge. During an initial gathering phase, like any field-worker, Omalius d'Halloy recorded facts gleaned while observing, and then jotted down without attention to formal aspects. ${ }^{17}$ Then, after the journey's end, he consigned to a notebook the detail of the route he followed. A 156 page register thus contains the details of Omalius d'Halloy's journeys during the 32 trips he went on between 1801 (Paris via Reims and Brussels) and 1845 (Naples). For each of these, he gave particulars about the places he went through, the route followed and the distance travelled. ${ }^{18}$ In other notebooks, he then reordered his observations and classified them in two distinct —and disproportionateparts : on the one hand he recorded some "notes on mineralogy and geology taken during the journeys", on the other, some "notes on objects other than mineralogy and geology". ${ }^{19}$ A final

\footnotetext{
15 Omalius d'Halloy's travel notes are held in the Archives de l'Académie Royale de Belgique, (Fonds d'Omalius d'Halloy, ${ }^{\circ} 8868-8871$, Voyages et excursions). The detail of his itineraries is indicated in a small volume entitled "Itinéraires", ${ }^{\circ} 8872$.

${ }^{16}$ Bourguet (Marie-Noëlle), Déchiffrer la France : la statistique départementale à l'époque napoléonienne, Paris, Editions des archives contemporaines, 1989; Cooper (Alix), “The Possibilities of the Land': The Inventory of 'Natural Riches' in the Early Modern German Territories", Annual Supplement to Volume 35 History of Political Economy, edited by Margaret Schabas and Neil de Marchi, Duke University Press, Durham and London, 2003, p. 129-153.

${ }^{17}$ Archives de l'Académie royale de Belgique, $\mathrm{n}^{\circ} 8869$ and $\mathrm{n}^{\circ} 8876$.

${ }^{18}$ Archives de l'Académie royale de Belgique, $\mathrm{n}^{\circ} 8872$. A draft of this notebook is conserved under $\mathrm{n}^{\circ} 8879$.

${ }^{19}$ Archives de l'Académie royale de Belgique, $\mathrm{n}^{\circ} 8868$.
} 
register enabled him to synthesize his knowledge. ${ }^{20}$ This register contains 427 folios of bound notes concerning the 130 departments composing the French Empire in 1812, in alphabetical order. On each "card", Omalius d'Halloy synthesized the geological information he had gathered on the department concerned. When the information did not stem from his own observations, he indicated their origin; most often they were data passed on by prefects or sub-prefects, or information he found in his readings (Journal des mines, Journal de physique, a few treatises whose authors are quoted: the names of Desmarest, Gensanne, Soulavie, Pasumot, Bertrand, etc. emerge frequently). ${ }^{21}$ Each notebook completes the others ${ }^{22}$ and, while Omalius d'Halloy conceived this organization as early as 1806, over the following years, he attempted to make it ever more consistent with his scholarly ambitions. ${ }^{23}$

This obsession with giving a meaning to field observations also appears in the letters the young geologist regularly sent to Charles-Etienne Coquebert de Montbret, as well as to his son Eugène who continued to work at the Ministry of the Interior. This correspondence relates, often with details, the field work and the cartographic results it produced. Indeed, in 1811, the imperial administration expected Omalius d'Halloy not only to transmit his observations, but also to transfer them onto a map. ${ }^{24}$ His letters thus give evidence of the construction of "his" own map, as well as of the additions or corrections he made on those

\footnotetext{
${ }^{20}$ Archives de l'Académie royale de Belgique, $\mathrm{n}^{\circ} 8873$.

21 "Alpes hautes: The prefect of the hautes Alpes has provided, on September 2, 1808, a map with these indications:

$1^{\circ}$. What is comprised inside the red line is primary rock where limestone can be found, but in very small quantity.

$2^{\circ}$. What is between the blue lines is primary rock mixed with limestone which constitutes the majority.

$3^{\circ}$. The rest which forms the low part and about half the department is limestone where primary rock can only be accidentally found and where one presumes it has been carried by main streams.

The red line begins near the road from Grenoble to Sisteron... (...) [he thus described the laying out of the red line and the blue line]"; "It seems that the surroundings of Briançon are formed of serpentine [dubious transcription], calcareous and schistose rocks (Guettard), as a result I suppose they are greatly related to the southern part of the Val d'Aosta", Archives de l'Académie royale de Belgique, nº 8873, fol. 9.

${ }_{22}^{2}$ In a footnote, Omalius d'Halloy thus detailed: "The geographical and political situation of all the places I went through being indicated in the itineraries, I shall not give any notion of their position, but when I speak of the places not mentioned in the itineraries, I shall indicate in brackets, according to the circumstances, their region, the number of their arrondissement, their department, and the distance to a known town.", Archives de l'Académie royale de Belgique, $\mathrm{n}^{\circ} 8868$, fol. 1 .

23 "Nota : I thought that it would be better to place with the geological notes all that concerns the physical constitution according to its aspect, soil, and vegetable production, etc. considered in a general way, while the agricultural details would be consigned to the other notes. This distribution begins with this journey.", Archives de l'Académie royale de Belgique, $\mathrm{n}^{\circ}$ 8868, fol. 84 "Notes prises dans un voyage aux montagnes des Vosges, en juin et juillet 1807 ".

${ }^{24}$ To draw the "geological map of the French Empire", Omalius d'Halloy had to transfer the field observations he made on an administrative map. Lacking specific surveys, he applied the method that Ami Boué, the president of the Société de géologie, still recommended a few years later in his Guide du géologue-voyageur: "For the construction of geological maps, one has to use the best geographical maps, if there are any existent, and to try and colour during the journey even those on the biggest scales", Boué (Ami), Guide du géologue-voyageur sur le modèle de l'agenda geognostica de M. Leonhard, Paris, F.G. Levrault, 1835-1836, vol. 1, p. 150.
} 
drawn by the Statistics Bureau from the data transmitted by the prefects. His specialist's gaze enabled him to verify in the field the accuracy of the information transmitted by the local administrators. He then would indicate to Eugène Coquebert de Montbret corrections to make on these maps. ${ }^{25}$ In July 1811, while he was staying in Tulle, Omalius d'Halloy wrote a letter to Charles-Etienne Coquebert de Montbret who was then in Amsterdam, in which he specified:

"We had obtained quite good information on the northern limit of granite in the centre, I have just crossed it in the two areas about which the details were more dubious, i.e. at Cullau in the Cher and at Montmorillon in the Vienne. I have also been able to understand the map you were sent from the Charente and I have verified or rectified almost all the western line of the primary rock up to the Corrèze.".26

As this letter shows, Omalius d'Halloy outwardly respected the demands of the Statistics Bureau: to construct a map as complete and precise as possible. Certainly the beginning of his correspondence shows that he scrupulously followed the advice of Charles-Etienne Coquebert de Montbret $^{27}$, and that he faithfully answered the questions addressed to him regarding the "geological map of the Empire": he verified, corrected, rectified, and often completed the cartographic documents which had been transmitted to him before his departure.

Yet, after a few weeks, divergences between the instructions given and the practices implemented appeared. Simply put, Omalius d'Halloy displayed his own logic, that of the field-worker preoccupied with geological configurations. On July 25, 1811, he justified his change of itinerary in the following reply to Coquebert de Montbret:

"I have not gone to the department of Mayenne, which you were describing in your letter, for since your departure information arrived which, added to the knowledge we have of the Sarthe thanks to the map of the prefect Mr. Ménard and my passage there, enables us to judge rather accurately of these

\footnotetext{
${ }^{25}$ Bibliothèque municipale of Rouen, Ms Mbt 11, Letter from Omalius d'Halloy to Eugène Coquebert de Montbret, Clermont, August 21, 1811: "Our Aveyron is well drawn but very badly coloured, there is in this regard many corrections to make, which would take too much time to explain to you right now, I shall touch a few words to Brongniart."; Bibliothèque municipale of Rouen, Ms Mbt 1013 - fol. 260, Letter from Omalius d'Halloy to Eugène Coquebert de Montbret, Emptinnes, October 12, 1811: "I have been through the dept of Allier in several directions and I have found there a few corrections to make on our work on the map. I have then gone through the primary range connecting the Morvan to the mountains situated beyond the Rhône and the Loire, the Saône plain, then through the Jura up to Neufchâtel from where I came back to Besançon. This section of the Jura has a different configuration from that of the department of the Haut-Rhin, in which the longitudinal crests are separated by extremely deep valleys; on the other side, they are separated only by shallow plains so that this part of the Jura looks like what Mr. de Humboldt tells us about Mexico. It is a wide and vast high plateau set between two plains".

${ }^{26}$ Bibliothèque municipale of Rouen, Ms Mbt 11, Letter from Omalius d'Halloy to Charles-Etienne Coquebert de Montbret, Tulles, July 25, 1811 [Coquebert de Montbret was then in Amsterdam].

27 This attitude is also perceptible in the letters addressed by Omalius d'Halloy to Eugène Coquebert de Montbret. He evoked, for example, the "work in which Mr. your father had allowed me to second him", and noted later on "since I have been here, I have lost no time in following your father's advice and I learnt German", Bibliothèque nationale de France, Ms NAF 20078, fol. 42, Letter from Omalius d'Halloy to Eugène Coquebert de Montbret, from Liège, January 2, 1810.
} 
parts. I have visited two other bocage lands very far from each other, the Perche and the Puysaie, on whose geology I wished to have a few notions and which stimulated quite singular ideas." 28

The gap between the official aim of this journey and Omalius d'Halloy's project quickly emerged. While he was supposed to take part in the statistical inquiry and was expected to transmit geological data on each department, questions of a geological nature increasingly determined his itinerary, making him lose sight of the contiguity which was intended to prevail in his journey of investigation. Omalius d'Halloy expressed this difference himself in a letter he sent to Eugène in October 1811:

"It has been a long time already, My dear Sir, since I felt confident enough to send you some news, and yet I have nothing of great importance to announce; you may have seen in my correspondence with Mr. Brongniart what has occupied me most on the banks of the Allier and the Loire superior, things which, however, would not have been of much interest to you because the formation of soft water doesn't lead to very remarkable statistical results. ${ }^{, 29}$

Omalius d'Halloy never lost sight of the mission entrusted to him by the Statistics Bureau, and he gave Eugène Coquebert de Montbret very precise indications regarding the geological map of the Empire, but curiosity concerning geological units triumphed over, or at least prevailed over, the gathering of statistical data on each department. ${ }^{30}$ Despite the precision with which he answered the expectations of Coquebert de Montbret, father and son, Omalius d'Halloy distinguished between acquiring geological knowledge of a region and transmitting data - even of a geological nature - to the Statistics Bureau. The first goal required more sustained observations than the second and, above all, observations which were not determined by administrative divisions. This distinction emerges in the comparison of the letters Omalius d'Halloy wrote at the same time - and sometimes on the same day- to Eugène Coquebert de Montbret and to Alexandre Brongniart. To the former, he transmitted precise information concerning the geology of a specific department, to the latter he did his utmost to present expanses of homogeneous terrain. ${ }^{31}$

\footnotetext{
${ }^{28}$ Bibliothèque municipale of Rouen, Ms Mbt 11, Letter from Omalius d'Halloy to Charles-Etienne Coquebert de Montbret, Tulles, July 25, 1811 [Coquebert de Montbret was then in Amsterdam].

${ }^{29}$ Bibliothèque municipale of Rouen, Ms Mbt 1013 - fol. 260, Letter from Omalius d'Halloy to Eugène Coquebert de Montbret, Emptinnes, October 12, 1811.

${ }^{30}$ From Tulles he thus wrote: "I have verified or rectified our whole western limit up to the Corrèze via Curay Champagne-Mouton, La Rochefoucauld, etc. which has also taught me how to correct the famous map of Charente, but I made a mistake in placing a point of granite in the west, by Champagne-Mouton (Charente), if there are, like the map announces, some areas of granite not far from Buffee, it is only an isolated point detached from the big mass which more or less follows the course of the Vienne from Isle Jourdain up until Pont Sigolant. Earlier I went to look at Lapuysaie or the bocage of the Yonne whose geology I felt like knowing, I do not consider this land at all as alluvium, it is like the Perche, Touraine, etc. layers of sand, flint, clay, marl, etc. which belong to the formation of chalk and are one of its most ancient terms". Bibliothèque municipale of Rouen, Ms Mbt 11, Letter from Omalius d'Halloy to Eugène Coquebert de Montbret, Tulles, July 25, 1811.

${ }^{31}$ On July 25, 1811, he wrote to Coquebert de Montbret: "Having just written a long letter to Mr. Brongniart which might first arrive in your hands, I shall not repeat what I said in that letter but I shall tell you that I have entered the primary terrain from the point about which we had the least information, i.e. the Cher, and I have
} 
Not only did Omalius d'Halloy's gaze sharpen in the contact with the field, but he also used his observations to suggest new questions to address to the prefects and sub-prefects. As early as July 1, 1811, he wrote to Eugène:

"It could be advantageous that, in your moment of leisure, i.e. the least hurried, you acquire some information about the locations from which the stones that are used in Tours come. I already have some notions about this, but they could be more complete. One could say that it seems that there are four different kinds of stones $1^{\circ}$. The ordinary freestone which is a kind of white tufa $2^{\circ}$. Another coarser and more yellowish freestone, $3^{\circ}$. The hard stone used to make bridges, $4^{\circ}$. Finally, the stone used to make lime and paving blocks." 32

His field work enabled him to nourish the questionnaire which, more generally, contributed to the knowledge of natural regions. As noted earlier, Charles-Etienne Coquebert de Montbret considered the political subdivisions to be largely irrelevant, thus he sought to identify enduring limits, which, to him, meant getting acquainted with natural regularities. Omalius d'Halloy concurred with Coquebert de Montbret regarding the relevance of this category. ${ }^{33}$ Both scholar and administrator considered investigations at the departmental level to be outmoded in that they presupposed an observational framework unsuited to the object. However, Omalius d'Halloy went beyond Coquebert de Montbret's expectations in his privileging of geological configurations; on July 25, 1811, he wrote:

"I have attempted to determine the limits of the soft water ground of Paris and I have gone through a large part of the Beauce, this word which refers to a quite well characterized physical region is not entirely geological for there is a part of the Beauce which is made of chalk while the major part is made of soft water limestone." ${ }^{34}$

found this soil a little further to the north than we had guessed on the map, i.e. at 9 1. north from Cullau", Bibliothèque municipale of Rouen, Ms Mbt 11, Letter from Omalius d'Halloy to Eugène Coquebert de Montbret, Tulles, July 25, 1811.

On the same day, he wrote to Alexandre Brongniart: "From Orléans, I headed for Montargis and Auxerre and I have seen the limits of soft water limestone near the first of these towns, and those of chalk near the second. This last passage shows a very instructive fact, i.e. that the first layers of limestone alternate here with clay, which explains all these valleys of clay which we find on the oriental border of chalk. When crossing the Loire again between Cosne and Giens, I found yet again the soft water limestone as it should be, i.e. forming the bottom of the valley and embanked between hills of what I call ancient chalk. Between Aubigny and Bourges, I saw the limit between this ancient chalk and ancient limestone, since this limit is clear-cut along the entire oriental border", Bibliothèque municipale of Rouen, Ms Mbt 11, Letter from Omalius d'Halloy to Alexandre Brongniart, Tulles, July 25, 1811.

${ }^{32}$ Bibliothèque municipale of Rouen, Ms Mbt 11, Letter from Omalius d'Halloy to Eugène Coquebert de Montbret, Orléans, July 1, 1811.

33 "In general, all of these departments are highly instructive for all naturalists. If the people who have described the Aveyron had considered it according to physical regions, their work would have been very interesting for they would have made known without leaving the department the granitic land of the Limousin, the volcanic terrain of the Auvergne, the secondary mountains of the Cévennes, the alpine region of the montagne noire, the calcareous plateaux of the Lot, etc.”, Bibliothèque municipale of Rouen, Ms Mbt 11, Letter from Omalius d'Halloy to Charles-Etienne Coquebert de Montbret, September 29, 1811, from Emptinnes near Namur [Coquebert de Montbret was then in Amsterdam].

${ }^{34}$ Bibliothèque municipale of Rouen, Ms Mbt 11, Letter from Omalius d'Halloy to Charles-Etienne Coquebert de Montbret, Tulles, July 25, 1811 [Coquebert de Montbret was then in Amsterdam]. 
For Coquebert de Montbret however, a physical region represented a much wider category: "any area of France distinguished by a particular physical feature" ${ }^{, 35}$, or "a region whose different parts offer natural analogies instead of arbitrary and variable relations resulting from political divisions". ${ }^{36}$ Omalius d'Halloy proposed a narrower meaning, only considering the nature of the terrain. ${ }^{37}$

While he did not exclude the search for correlations, for example between geological and agricultural data, the young geologist nevertheless took care not to propose hasty conclusions based on approximate analogies: he carefully detailed the facts he observed and was wary of all systemic generalizations. ${ }^{38}$ When he considered the localization of particular vegetables as useful in the construction of geological hypotheses, he sought to study thoroughly the available data: in a letter written to Eugène Coquebert de Montbret from Clermont, on August 21,1811 , he thus recommended that sub-prefects be questioned concerning the distribution of chestnut trees. ${ }^{39}$ When Omalius d'Halloy based his reflection on external signs, he was aware

\footnotetext{
${ }^{35}$ During the meeting of March 12, 1824, Coquebert de Montbret brought in several subjects of prizes and the commission adopted one of them entitled "complete description of one of the natural regions of France" (cf. Bulletin de la Société de géographie, vol. II, 1824, Meeting of March 12, 1824, p. 32.). This prize was thus announced shortly after: "The Société proposes a competition on the following subject: Physical description of any part of the French territory forming a natural region. The Sociéte indicates as examples the following regions, the Cévennes proper, the Vosges, the Corbières, the Morvan, the Basin of the Adour, of the Charente, of the Cher, of the Tarn, the delta of the Rhône, the low coast between the Sables d'Olonnes and Marennes, the Sologne, indeed any region of France distinguished by a particular physical character. The physical and moral relations of man, when they lead to new observations, must be linked to the description of the region. The memoirs must be accompanied by a map indicating the trigonometrical and barometric heights of the principal points of the mountains, as well as the slope and the speed of the main rivers and the limits of various vegetations", cf. Bulletin de la Société de géographie, vol. II, 1824, p. 43.

36 "Their authors seem to have thought that by asking for the description of a natural region, the society had meant a purely physical description, while its aim was that, after having substituted limits found in nature to those given by administrative circumscriptions, and having thus determined a region whose different parts offered natural analogies instead of arbitrary and varying relations resulting from political divisions, one applied oneself to describing such a region with all the details comprised in a good special geography, and in particular that one would not neglect to make known the number, the physical constitution, the mores, the occupations of the inhabitants, i.e. how the programme, the physical and moral relations of the region express themselves", Bulletin de la Société de géographie, volume IX, 1828, page 143.

${ }^{37}$ In 1808, in his Essai sur la géologie du Nord de la France, Omalius d'Halloy proposed to "draw on a map (...) the space occupied by each kind of terrain". Omalius d'Halloy (Jean-Baptiste Julien d'), Essai sur la géologie du Nord de la France, Paris, Bossange, 1809 [It is an offprint of the long article published in 1808 in the Journal des mines, ${ }^{\circ} 140$ and 141].

38 "We now have a good enough grasp of the arrondissement of Saint Amand to obtain good results, like those you have from la Châtre which I now understand very well. One should ask first for the reports of the communes where wheat is cultivated and those where only rye is cultivated, all this considered in a general way and not by particular exception, one should then make observations on the fact that it appears that each terrain dedicated to wheat lies on limestone and those dedicated to rye on a sandy terrain where [one finds] foliated rocks called schist, [finally one should] ask in what measure this is true and learn about the exceptions. If there are any, one should then add we would like to know if possible which are the known [places] where one finds foliated rocks or schists similar to those of Cullau and Préverange, those where there are only sands, and [those] where one finds reddish coarse sandstone similar to that we have brought to St Amand.", Bibliothèque municipale of Rouen, Ms Mbt 11, Letter from Omalius d'Halloy to Eugène Coquebert de Montbret, Tulles, July 25, 1811.

39 "I suppose you have a work on the chestnut trees in the Lot, if you don't have it, it would be good to ask for it, above all in the arrondissements of Gourdon and Cahors for, beside the fact that it is interesting in itself, some
} 
of the complexity of the correlations, and his experience of the field prevented him from drawing hasty conclusions. ${ }^{40}$ In the same way, he attracted Eugène's attention to the necessary caution required to study the localization of vines:

"I have some causes to suspect that the separation of the mountain from the vineyards that the prefect of the Doubs has highlighted has no geological effects and that it only comes from the fact that the valley of the Doubs, being very hollow, has allowed vines to develop".

In these circumstances, the Statistics Bureau of the Ministry of the Interior emerged as an intermediary authority. Faced with the hypotheses formulated by the field work of Omalius d'Halloy, they were able to obtain, if not answers, at any rate data likely to invalidate or confirm his conclusions. He not only suggested new questions to the public authorities, but he also applied himself to formulating these questions; ${ }^{42}$ his experience of the field forged his status as an expert. The young geologist not only collected facts, but he also suggested interpretations and, in this way, he quite often exceeded the strictly statistical expectations. Moreover, it was these observations which made Omalius d'Halloy pay close attention to the question of scale and which stimulated his cautiousness regarding the correlations that Coquebert de Montbret imagined from a distance. The latter's questionnaire nourished the former's reflection, yet the field-worker was able to construct his route and direct his gaze according to his own interpretive grid.

The letters Omalius d'Halloy sent to Alexandre Brongniart give evidence of the conception he had of the fieldwork of the "geologist". He attributed a critical role to the geologist's ability to interpret observed phenomena, and connected this aspect of the work to the delimitation of the space under consideration. On August 19, 1811, he wrote to Brongniart:

geological consequences could result from this, concerning the limits of the two terrains which I call horizontal limestone and arched limestone. This tree seems particularly to dislike this last formation.", Bibliothèque municipale of Rouen, Ms Mbt 11, Letter from Omalius d'Halloy to Eugène Coquebert de Montbret, Clermont, August 21, 1811.

${ }^{40}$ He wrote, moreover: "on this side, the geology is not related to culture. The primary rock, on the banks of the Gartempe between Bellard and Montmorillon, produces wheat and the calcareous terrain covered with this unfortunate layer of flint and sand from the Touraine also presents vast moors. In the Charente and the Dordogne, the chestnut trees are not related to geology either, they emerge in similar ways and are just as plentiful on both terrains, but one has to note that both are equally covered with a sandy layer for in the surroundings of Montignac where limestone is uncovered, the chestnut tree disappears.", Bibliothèque municipale of Rouen, Ms Mbt 11, Letter from Omalius d'Halloy to Eugène Coquebert de Montbret, Tulles, July $25,1811$.

${ }^{41}$ Bibliothèque municipale of Rouen, Ms Mbt 1013 - fol. 260, Letter from Omalius d'Halloy to Eugène Coquebert de Montbret, Emptinnes, October 12, 1811.

42 "We badly stated the question for the Tarn and the Tarn et Garonne by asking about the state of the lime kilns. This deserves examination by naturalists with more time, for it appears that there are good limestones which are not good for building and which belong to the alluvial formation of the plain; to reach our aim the best way to put the question would be to ask those two prefects of Villefranche (Haute-Garonne) for a report on the communes where one generally builds with stone and on those where brick and pisé are more commonly used. We would then have the means to identify the kinds of stones.", Bibliothèque municipale of Rouen, Ms Mbt 11, Letter from Omalius d'Halloy to Eugène Coquebert de Montbret, Clermont, August 21, 1811. 
"I find you excessively modest in the way you judge yourself given your regrets about not travelling. Even if you were forced to stop, which will not be, you would not be less of a geologist, and an outstanding one at that. You have done just as much as our German masters; they have given us a Saxon geology, you have given us a Parisian geology. You have done better than them, for they have presented the Saxon geology as a general geology and they have sometimes been wrong. You have presented your geology as only applying to the terrain of Paris and your main facts will be indisputable forever.",33

The remainder of the letter evokes the indispensable familiarity of the geologist with his field.

Omalius d'Halloy travelled on foot and was quite attached to that practice, which he considered essential for all intellectual projects. Seeing constituted for him a necessary stage in the construction of learning:

"One cannot be sufficiently wary of drawing general consequences from what one has seen in a country. I think one should only have general ideas after having seen the whole earth, i.e. never. I started by seeing my country, and only my country; all went wonderfully then. I had a geology of the Ardennes which I though possible to apply to the whole universe, I then went to the Alps, I had to make changes, and I made for myself a Ardenno-Alpine geology which I still believed to be general. Today, I still have to change but as man's mind naturally loves to generalize all this will work out all right and I shall soon have a Cevenno-Ardenno-Alpine geology. I feel however that this will be the last one, for if I still am able to travel, the combination of names will become too large, I shall retain only isolated facts and (...) I shall be like the great Saussure who ended up losing all theoretical ideas." 44

At that time, the geologist had to define his relation to the field in opposition with two models from which he sought to liberate himself: he had to get rid of the spirit of system displayed by the authors of earth theories, but he also had to beware of the naturalists who collected facts while forgetting to observe the relations existing between them. Omalius d'Halloy's correspondence reveals how the experience of the field - nourished, of course, by all the descriptive texts which, at that time, sought to characterize the principles of observationplayed a determining role in the construction of his geology, and probably enabled him to appreciate nature's complexity, as well as the limits of its restitution, whether textual or cartographic. $^{45}$

However, in 1813-1814, while he was trying to synthesize all the data he had in his possession - to carry out the order he received-, he not only wrote a text, but also constructed a map, precisely the one which would, seven or eight years later, act as a starting point for the publishing venture. The maps preserved in the Montbret Collection at Rouen's municipal library allow one to restitute the genealogy of this map.

\footnotetext{
${ }^{43}$ Bibliothèque municipale of Rouen, Ms Mbt 11, Letter from Omalius d'Halloy to Alexandre Brongniart, from Clermont, August 19, 1811.

${ }^{44}$ Idem.

45 Cooper (Alix), "From the Alps to Egypt (and back again): Dolomieu, Scientific Voyaging, and the Construction of the Field in the Eighteenth-Century Natural History", in Making Space for Science. Territorial Themes in the Shaping of Knowledge, edited by Crosbie Smith and John Agar, London, Macmillan Press, 1998, p. 39-63.
} 


\section{The synthesis and the map: the successive manuscript drafts}

Coquebert de Montbret's geographical map collection comprises 868 references listed in a catalogue and classified by geographical areas, as well as about 200 unlisted documents. ${ }^{46}$ While there is a heading entitled "Physical geography - Mountains" which includes the maps of Marsigli, Buache, Bourcet, Raymond, Roussel, Desmarest, etc., there is no heading for geological maps, which are in fact scattered under the different geographical headings. Except a few exceptions - the map of William Smith in particular-, these geological maps are actually administrative maps on which geological data have been added by hand, either by Charles-Etienne Coquebert de Montbret, his son Eugène, or by scholars who sent him their work. ${ }^{47}$ Some thirty such documents appear in the collection, and it is among them that we have attempted to unearth the maps which might have have been used as drafts for the 1823 map.

The task is not as simple as it may seem, for Coquebert de Montbret transfered geological data on many maps of France. A few of the 182 folios of Cassini's map bear patches of colour whose origin Coquebert de Montbret usually indicated. At the back of the Saint-Flour sheet, he noted: "coloured partly according to information given by Mr. Veyne - Map of Mende", and added "the colours placed in the western part come from Mr. de Veysse de Chaliac, from Saint-Flour. Blue stands for volcanic, red is by CM [probably himself]". This use of the sheets of Cassini's map is far from systematic, but the list of sheets bearing geological annotations

\footnotetext{
${ }^{46}$ Laboulais (Isabelle), "Reading a Vision of Space...", op. cit. See also the presentation of this collection, as well as the first results of the digitalization campaign in progress at the following address: http://misha1.ustrasbg.fr/cdm/

${ }^{47}$ One notes that Coquebert de Montbret used the same procedure to try and synthetize agricultural data: cf. Montbret Carte 324 : Galliae seu Franciae Tabula qua omnes Provinciae, viae angiariae et aliae res notatu digniae, distincte et peraccurate ostenduntur per Nicolas Visser, Amsterdam, vers 1670, env. 1: 2400000 ; Montbret Carte 656: Regionum coloniense electoratu et archiepiscopatu subditarum peraccurata tabula, per Nicolas Visser, Amsterdam, 1710, 1:260 000 ; Montbret Carte 933 (3 et 9) : Carte de la France divisée en 110 départemens subdivisée en arrondissements communaux par Belleyme, Paris, 1806; Montbret Carte 934 : Département de l'Ain, Atlas pour servir à l'intelligence de la statistique générale de la France publiée par ordre de Sa Majesté l'Empereur et roi dirigé par Belleyme Ingr géographe, chez Testu, env. 1810, 1: 345600 ; Montbret Carte 938: Carte du département de la Drôme avec ses différentes subdivisions sous les rapports administratifs, judiciaires et religieux dressée à Valence en l'an 12 par ordre du préfet ; Montbret Carte 940 : Département des Landes pour servir à l'intelligence d'un mémoire pour servir à l'amélioration des laines des Landes par M. Poyféré de Cere, M. Valentin du Plantier préfet, 1805; Montbret Carte 944 : Carte du département des Vosges divisée en arrondissemens de sous préfectures et de justices de paix, dressée et dessinée par Ogard arpenteur géomètre à Epinal, s.d.]. The same holds for the linguistic practices he had gathered while working at the Statistics Bureau [cf Montbret Carte 640 : Carte du Tyrol. Karte der Gefürsteten Grafschaft Tyrol nach den vortrefflichen Karten des Peter Anich und Blasius Huber (...) von Joseph Kipferling, Wien, 1804, 1 : 540000 , Montbret Carte 641 : Carte von Tyrol nach Peter Anich und neuern Hülfsquellen verfast von I.E.S., Wien, 1801, 1:322 000; Montbret Carte 943 : Carte du département de la Moselle dédiée à M. Colchen préfet, Verrannais, Imprimeur à Metz, an XIII].
} 
suggests he was in the habit of taking them with him while travelling, at least when he went to Brittany in 1818 and to the Cévennes in 1821, for he often indicated on the document that the colored additions were made on site. The choice of a large scale seems suited to acquiring a direct knowledge of the territory, allowing great precision in the details of the terrain, but without permitting exhaustivity. This series does not seem to have been used to consign Omalius d'Halloy's observations.

The same observation can be made regarding Chanlaire's Atlas national. Coquebert de Montbret owned two series which both bear annotations on geology and the distribution of cultures. Only a few sheets were coloured, yet not all were coloured according to the observations collected by Omalius d'Halloy. ${ }^{48}$ Eugène Coquebert de Montbret copied the division of terrains according to a Mr. Devèze, engineer, to four pages pinned to the Cantal sheet $^{49}$, while a key on the map of the Cher refers to a manuscript memoir dated 1828. Only two sheets are related to Omalius d'Halloy's work: the map of the Mont Tonnerre ${ }^{50}$ and that of the Sarre ${ }^{51}$, with the following inscription on both: "we have coloured on this map the places where Messrs Bonnard and Omalius d'Halloy observed the nature of the terrain". Both maps have similar keys. ${ }^{52}$

The traces of Omalius d'Halloy's observations are more visible on the 18 sheets of Capitaine's map on a scale of $1: 345600,{ }^{53}$ this series being the one Coquebert de Montbret systematically used to consign all the geological information in his possession. Thus not only does the whole series bear traces of repeated consultations - each sheet is identified by a number and a title-, but each sheet offers geological information of varying density. The information on the map comes from three different sources: Coquebert de Montbret gathered there his own field observations, but also remarks from his readings, as well as information transmitted by his correspondents. On the sheet representing the Bresse, the Dauphiné and the Savoy, he thus indicated that this map was "coloured according to the map communicated by

\footnotetext{
${ }^{48}$ However a few sheets are partly coloured without any reference to the source used: that of the Pas de Calais (Bibliothèque municipale of Rouen, Montbret Carte 333-37), that of the Cher (Bibliothèque municipale of Rouen, Montbret Carte 333-6a), that of the Maine et Loire (Bibliothèque municipale of Rouen, Montbret Carte 349-37), and that of the Manche (Bibliothèque municipale of Rouen, Montbret Carte 349-40d).

${ }^{49}$ cf. Montbret Carte 349, fol. 12b2A (key).

50 cf. Montbret Carte 349, fol. 47.

${ }^{51}$ cf. Montbret Carte 349, fol. 61.

52 While the content differed slightly from one sheet to the other, the colour codes nevertheless remained identical. This difference can be explained simply by the absence of porphyry in Sarre and the absence of transitional limestone at Mont-Tonnerre.

53 cf. Montbret Carte 332 : Carte de la France dédiée au Roi Par les Directeurs et Associés de la carte de la France. Réduite sur l'Echelle d'une ligne pour 400 Toises d'après les 180 Feuilles de la grande Carte de la France levée géométriquement par ordre du Roi sur l'Echelle d'une ligne pour 100 Toises, 1789, 1 : 345600.
} 
Mr. Héricart de Thury". ${ }^{44}$ [cf. Montbret carte 332, op. cit., fol. 13]. This series seems to have enabled Coquebert de Montbret to centralize heterogeneous information: in this case mostly geological information, but one also finds references on some sheets concerning linguistic inquiries or agricultural practices. Most often, the geological considerations, which stem from his own observations or from the network of mining agents, are noted in the margins or on the map itself; they appear textually, symbolically, or as colour washings [cf. details Montbret Carte 332, op. cit.]. Although it is not attached to the series, it seems that a common key was used to colour the whole, a note on folio no. 4 indicates:

"This map is an exception to the colours adopted on the other folios, it is coloured after that of Mr. Brongniart, pink stands for chalk, yellow for the coarse limestone found in the vicinity of Paris, purple for siliceous limestone, blue for gypsum, red for sandstone, green in hachures for the formation of soft water, only the limits of the Champagne chalk, traced by Mr. Desmarest, are nevertheless in red, the discontinuous pale blue line indicates the limit of the vine." 55

This note suggests the coexistence of two differents keys, yet the consultation of the whole series testifies to the multitude of systems imagined by early nineteenth century geologists to colour their maps. In this matter, uncertainty reigns regarding both the definition of the categories, and the correspondence between colours and kinds of terrain. Thus for Brongniart red stands for sandstone, for Omalius d'Halloy and Bonnard it stands for volcanic terrain, while it is absent from Héricart de Thury's nomenclature... In spite of the note mentioned earlier, it seems that uniformity of colour codes was a wish rather than a principle. On certain sheets, a very succinct key is indicated: on folio no. 6, it distinguishes granite, gneiss, diabase, etc (pale pink), slate (blue), red sandstone (purple) and horizontal limestone (yellow); on folio no. 9, the key also comprises four categories: one finds again granite, gneiss, etc (still in pale pink), then ancient horizontal limestone (light grey), chalk (pale yellow) and soft water limestone (pale orange). This collection, constituted at the moment when geologists were attempting to formalize their cartographic representations, testifies to the intensity of the reflections devoted to the establishment of both a nomenclature and a suitable colour system. ${ }^{56}$ Paying attention to the meaning of colour codes offered geologists a means to distinguish themselves from the mineralogists who were attached to symbolic signs.

\footnotetext{
${ }^{54}$ Bibliothèque municipale of Rouen, Montbret Carte 332 (13).

${ }_{55}^{5}$ Bibliothèque municipale of Rouen, Montbret Carte 332 (4).

56 "Right from the beginning of maps with colour-washed areas, the cartographer faced a long-lasting problem: the range of colours available was more restricted than the already identified list of distinct entities. This necessitated to consciously simplify reality a great deal. Moreover, it required drawing lines with simple outlines along the limit of the coloured areas, whereas in the field the limit of formations is quite festooned, forming islets, etc. The use of colour implies cutting down and synthesis", Ellenberger (François), "Recherches et réflexions sur la naissance de la cartographie géologique, en Europe et plus particulièrement en France", Histoire et nature, $\mathrm{n}^{\circ} 22-23,1983$, p. 34-35.
} 
In this collection, Capitaine's map constitutes the place of accumulation for data of heterogeneous object and origin and, in spite of Coquebert de Montbret's effort to determine the limit between different kinds of terrain, synthesis has no place here. Had it been among the ambitions assigned to this project, the method implemented would have doomed it to failure automatically: Coquebert de Montbret seemed to give the same credit to a delimitation indicated verbally during a conversation ${ }^{57}$ as to the one observed de visu by Omalius d'Halloy or others (Cordier, Charpentier in particular are cited on these maps).

Coquebert de Montbret used the maps just described to attempt to manage the profusion of data he accumulated. To consign Omalius d'Halloy's observations, he used the same technique but applied it to another map, that of France on a scale of 1: 880000 drawn by Pierre de Belleyme. Four copies of it are held in Coquebert de Montbret's map collection, ${ }^{58}$ all bearing explicit traces of the intensive use he had made of them. In one case, the map identified on the back as "France geological studies" is quite widely coloured but no key is mentioned. One can suppose that the areas left blank are those which had not been surveyed, or at least those on which Coquebert de Montbret had failed to collect enough reliable data to represent them graphically. Another of these maps represents a copy of the "mineralogical map sent to the Institut by Mr. de Charpentier in December 1822 "; 59 the printed version of this last map exists as well in Coquebert de Montbret's collection, since his colleagues of the Académie des sciences had entrusted him with presenting a report on this text. Coquebert de Montbret not only preserved Charpentier's map, he also copied its data onto another map, possibly to check their concordance with Omalius d'Halloy's conclusions, or maybe to complete knowledge of a part of the territory Omalius d'Halloy had not surveyed.

Another copy of this map is entitled "Essai d'une carte géologique de l'Empire français", 60 and is accompanied by two keys, one for the eleven tints used to colour-wash the map, the other for the thirty-eight signs used to indicate the localization of resources. The original

\footnotetext{
${ }^{57}$ On folio no. 9, Coquebert de Montbret has for example noted: "The yellow line indicates the limit of light terrain plains and stony regions. The northern part has been drawn following a conversation with Mr. Leschevin", Bibliothèque municipale of Rouen, Montbret Carte 332-9.

${ }^{58}$ This map of France on a scale of 1: 880000 was first published by Louis de Capitaine in 1790; after his death, Pierre de Belleyme resumed his work and published several versions of this map in connection with the evolution of the number of departments. If one considers the scale and content of the map, one can consider the different versions to be one and the same map. If one considers the authors, one must specify that Coquebert de Montbret owned a copy of Capitaine's map (Bibliothèque municipale of Rouen, Montbret Carte 331) and three of that of Belleyme (Bibliothèque municipale of Rouen, Montbret Carte 330, Montbret Carte 880, Montbret Carte 933).

${ }^{59}$ Bibliothèque municipale of Rouen, Montbret Carte 331.

${ }^{60}$ Bibliothèque municipale of Rouen, Montbret Carte 880.
} 
document has been cut into five strips of unequal size, each mounted on canvas. ${ }^{61}$ The form in which the map survives testifies to its intended use. Cut in this way, the map was obviously much easier to handle than a map whose dimensions measured $120 \mathrm{~cm} ;{ }^{62}$ the fourth and last copy of this map held in Coquebert de Montbret's collection was cut as well, this time in ten pieces, all of irregular size. A commentary added on the "Essai d'une carte géologique..." indicates that Coquebert de Montbret brought that map with him while travelling in France between the years 1816 and 1823 :

"On July 2, 1817 in Montpellier, Mr. Marcel de Serres touched up the part of the Cévennes that lies north of Montpellier; what he has encircled with a red line is, according to his observations, primary rock, granite, [?] etc. He does not believe coal to be found there, rather it is found in Le Vigan and above Alais. He marked in yellow the places in the vicinity of Montpellier where soft water limestone is to be found, he added more indications of volcanoes between Lodève and Agde."

All these indications were indeed added to the map in the course of the journey he undertook in the South of France in 1817, as several excerpts from his travel notebook show. But Coquebert de Montbret was probably not the only one who took this map with him during his journeys. In a letter Alexandre Brongniart wrote to Omalius d'Halloy on September 8, 1811, he noted: "I am off to Cherbourg, Rennes and Alençon, I am taking with me this part of your large coloured map of France and I shall work as best I can towards perfecting this great and beautiful work." ${ }^{63}$ No element on this map indicates its date, but one can without risk consider it to be a working document for Coquebert de Montbret and Omalius d'Halloy.

The key pinned to this "Essai d'une carte géologique de l'Empire français" shed light on the interactions between the two men. As if to differentiate himself from the young geologist, Coquebert de Montbret repeatedly noted in brackets "according to Mr. Omalius d'Halloy", although occasionally the words were later crossed out. The draft of this map shows that the categories themselves, i.e. the terms used to indicate the types of terrain, were not fixed. Red hachures thus represented not only volcanic outcrops and secondary unconsolidated beds, but also the "other rocks whose origins pose problem". Coquebert de Montbret also struck out the the term "shelly limestone" to replace it with "coarse or Parisian limestone". The key reveals how the two men proceeded by analogy, attempting to compare terrains they deemed similar in order to determine the major types of terrain. Next to the pink rectangle, the key thus

\footnotetext{
${ }^{61}$ The northern, the centre and the southern strip measure $86 \times 37 \mathrm{~cm}$, the eastern strip $26 \times 90 \mathrm{~cm}$, and that of western France is unfortunately lost, but it probably was of similar size as the eastern strip.

${ }^{62}$ The map measured 126 x $115 \mathrm{~cm}$. On this kind of map use, see: Jacob (Christian), L'Empire des cartes. Approche théorique de la cartographie à travers l'histoire, Paris, Albin Michel, 1992, p. 116.

${ }^{63}$ Archives de l'Académie royale de Belgique, $\mathrm{n}^{\circ}$ 8864, Scientific correspondence of J.J. Omalius d'Halloy, Letter from Alexandre Brongniart to Omalius d'Halloy, from Sèvres, September 8, 1811, fol. 125-128.
} 
indicates: "rocks thought to be primary such as can be seen in Limousin, in Brittany, including granite, gneiss, mica, schist, etc.”

The correspondence of Omalius d'Halloy and Coquebert de Montbret highlights the importance attached to the establishing of the key. As early as January 2, 1811, Omalius d'Halloy answered questions concerning the colours used on "the geological map of the Empire deposited in the study of VE". ${ }^{64}$ It appears that the indications he gave largely corresponded to the key of the Essai de carte géologique de l'Empire français. He explained that:

" $1{ }^{\circ}$. The yellow colour placed on the oriental side of the Vosges indicates a calcareous terrain in horizontal layers which may differ from the limestones occupying the great masses of the [illegible], of the Bourgogne, of the Cher, of the western coasts, etc., but we do not yet know enough to distinguish it from the latter, and we have temporarily represented it with the same colours. (...)

$2^{\circ}$. The orange colour of the vicinity of Saint Calais, Vendôme, etc. has been applied with great doubt, several suppose (particularly Mr. de Minard) that on [illegible] it indicates a limestone which [illegible] to that of Paris would be newer than chalk.

$3^{\circ}$. The brownish yellow of [illegible] of Pontoise indicates the limestone of Paris. The slight difference of hue between those two colours, which might be shocking on the map, comes from the fact that they have been applied at different times and that we had had the project of differentiating the limestone [illegible] from the limestone [illegible] but we have [illegible] and I am even more convinced that it will be impossible to indicate this difference on a map on such a small scale.

$4^{\circ}$. The light reddish brown of the Beauce indicates the millstone grits, siliceous sands, etc which lie on the horizontal limestone, the distinction of this terrain seems to me to present at the moment many defects [dubious transcription] I even fear we might be forced to [illegible] on our map all the formations of the Parisian Basin posterior to chalk. It is [illegible] we will be able to discuss with full knowledge of the facts when [illegible] the map of Messrs Brongniart and Cuvier is published.

$5^{\circ}$. The bluish green represents this terrain so abundant in the Alps which I refer to with Mr. [illegible] d'Aubuisson, etc. by the name of fo. of talcose schist and which is so well described in Mr. Brochant's memoir on the [illegible] limestone.

$6^{\circ}$. Pink indicates the terrain where granite is to be found, blue the slate, black the terrain with coal, grey marble and clayey schists [illegible], purple the red sandstone, pale yellow the chalk, bistre the light terrains called [illegible] of alluvium."

Omalius d'Halloy devised, however, other systems of colours: a few years later, when the two men were preparing the printing of their Essai d'une carte géologique, the young geologist reminded Coquebert de Montbret that he had established several systems, several examples of which exist in the map collection of Coquebert de Montbret.

\footnotetext{
${ }^{64}$ Archives de l'Académie royale de Belgique, ${ }^{\circ}$ 8864, Scientific correspondence of J.J. Omalius d'Halloy, Draft of a letter from J.J. Omalius d'Halloy to Eugène Coquebert de Montbret, January 2, 1811, fol. $244-245$.

65 Archives de l'Académie royale de Belgique, ${ }^{\circ}$ 8864, Scientific correspondence of J.J. Omalius d'Halloy, Draft of a letter from J.J. Omalius d'Halloy to Eugène Coquebert de Montbret, January 2, 1811, fol. $244-245$.
} 
It is obviously this map, or at least a fair copy of it, that was deposited at the Ecole des mines and in Alexandre Brongniart's study, who often refered to it in his letters to Omalius d'Halloy. Brongniart regularly evoked the weekly meetings he organized at home with his "faithful Sunday chatterers", 66 who were actually a small group of naturalists among whom Desmarest, Leman, Bonnard were the most assiduous. ${ }^{67}$ In his letter dated April 4, 1817, Brongniart reported to Omalius d'Halloy that his map had been the subject of their discussion:

"We talked about you a great deal last Sunday with Mr. de Buch who spent two hours studying the mineralogical map of France which you had offered me." ${ }^{\text {"68 }}$

As this example shows, the decision to publish this document reflected the scholarly world's interest in this "Essai d'une carte géologique".

\section{The vicissitudes of the publication}

On December 13, 1821, a few months after having presented his draft of an agricultural map to the Académie des sciences, Charles-Etienne Coquebert de Montbret wrote to Omalius d'Halloy to let him know his intention to publish the work completed seven or eight years earlier. He justified this step by the French backwardness in geological cartography, which he contrasted, of course, with the progressive ideas at work in England:

"Since we have worked you and me on the mineralogical map of France, nobody has published a similar work on the kingdom; whereas the English have brought to light the maps of Smith, Greenough and several others of the same kind." 69

Coquebert de Montbret explained to his former collaborator that recent journeys and numerous correspondences had reassured him as to the accuracy of the map produced in $1813 .^{70} \mathrm{He}$ therefore requested Omalius d'Halloy's agreement to open negotiations with the

\footnotetext{
${ }^{66}$ Archives de l'Académie royale de Belgique, $\mathrm{n}^{\circ}$ 8864, Scientific correspondence of J.J. Omalius d'Halloy, Letter from Alexandre Brongniart to Omalius d'Halloy, from Sèvres, March 29, 1812, fol. 139-141.

${ }^{67}$ Geologists or mineralogists also went to Brongniart's home during their stays in Paris. On March 24, 1815, he reported to Omalius d'Halloy: "Several English geognostics called on me, in particular Mr. Senle [dubious transcription] an Oxford professor, Mr. Greenough vice president of the London Geological Society, and Mr. Bundy [dubious transcription] president of this society. These gentlemen occasionally joined the Sunday matinée and we have frequently and at great length talked about you. They seem quite decided not to leave the continent without going to see you, they consider, with reason, this visit as a duty for any geognostic. I do not know whether they have carried out their project", Archives de l'Académie royale de Belgique, $\mathrm{n}^{\circ}$ 8864, Scientific correspondence of J.J. Omalius d'Halloy, Letter from Alexandre Brongniart to Omalius d'Halloy, from Sèvres, March 24, 1815, fol. 175-178.

${ }_{68}$ Archives de l'Académie royale de Belgique, $\mathrm{n}^{\circ}$ 8864, Scientific correspondence of J.J. Omalius d'Halloy, Letter from Alexandre Brongniart to Omalius d'Halloy, from Sèvres, April 4, 1817, fol. 179-184.

${ }^{69}$ Archives de l'Académie royale de Belgique, $\mathrm{n}^{\circ}$ 8864, Scientific correspondence of J.J. Omalius d'Halloy, Letter from Charles-Etienne Coquebert de Montbret to J.J. Omalius d'Halloy, December 13, 1821, fol. $268-271$.

70 "I took it upon myself this spring to present it before the Institut enriched with a few additions provided by friends or made by myself in the course of three journeys, one to Perpignan, Marseille, etc., the second in
} 
merchant in possession of the copperplates of Belleyme's map, which had served as a base for their "great geological and agricultural map". The letters Coquebert de Montbret wrote to Omalius d'Halloy up until 1823 show the difficulties, and then the failure of negotiations initiated with several different map merchants. ${ }^{71}$ In his letter dated March 14, 1823, he described his disappointments with bitterness:

"Regarding the great geological and agricultural map, Mr. Goujon, in his infinite wisdom, considered that putting our indications on Belleyme's map would spoil it, and since the copperplates are now in his possession, he consequently asked without any shame for indemnities to do so." ${ }^{, 72}$

He went on:

"I have found other people easier to deal with, who not only do not ask for anything to give it to the public, but even promise a number of copies to the authors. I beg to send you the brochure in which they announce this map, but only promising it for next September.,"73

However this attempt seems to have failed as well.

A careful reading of Omalius d'Halloy's correspondence shows that the initiative and the choice of publishing the Essai d'une carte géologique de la France at Berthe's were not a consequence, as has been long thought, of Coquebert de Montbret's approaches. ${ }^{74}$ Its publication, on the contrary, stemmed from the personal initiative of the geologist, now governor of the province of Namur, an initiative that the former director of the Statistics Bureau apparently did not consider as rival to his own. ${ }^{75}$ Thus, on March 14, 1823, while Omalius d'Halloy's Essai d'une carte géologique... was already out, he still evoked his

Brittany, and the third from which I am just back in the Cévennes, in Grenoble and in Besançon. I convinced myself in these journeys that our map is generally accurate.", Idem.

71 "The fact is that Mr. de la Marche, after having suffered all the slowness of the legal formalities on the occasion of the death of his partner, has ended up selling by auction the articles which composed his business. Belleyme's map (I mean the engraved plates of this map) was among them and Mr. de la Marche had sent to tell me that this article having gone higher than the price he wanted to pay for it, had been knocked down to $\mathrm{Mr}$. Goujon, seller of geographical maps, rue du Bas, no. 6. As soon as I received this piece of information, I sent somebody at Mr. Goujon's, being kept at home by an indisposition, and I learnt that he was himself bedridden and thus could not deal with any matter of business, but that as soon as he recovers, he would come and see me.", Archives de l'Académie royale de Belgique, n 8864, Scientific correspondence of J.J. Omalius d'Halloy, Letter from Charles-Etienne Coquebert de Montbret to J.J. Omalius d'Halloy, November 3, 1822, fol. $274-276$.

${ }^{72}$ Archives de l'Académie royale de Belgique, ${ }^{\circ}$ 8864, Scientific correspondence of J.J. Omalius d'Halloy, Letter from Charles-Etienne Coquebert de Montbret to J.J. Omalius d'Halloy, March 14, 1823, fol. $278-279$.

${ }^{73}$ Idem.

${ }^{74}$ In a letter dated December 29, 1822, the young man sent by Omalius d'Halloy to Paris to represent him wrote to him that Berthe having now been paid, he had recruited "six women to colour, so that, it seems to me, at least 15 days will have to pass before I come into possession of your 200 copies." Yet at this date, Coquebert de Montbret was still negotiating with Goujon. Archives de l'Académie royale de Belgique, ${ }^{\circ} 8864$, Scientific correspondence of J.J. Omalius d'Halloy, Letter from Del Marmol de Saint Marc to J.J. Omalius d'Halloy, December 29, 1822, fol. 468.

75 "Mr. Coquebert had told me to ask you for the permission to have 20 copies of the map printed in black to make different observations and annotations on it, and as Mr. Berthe had printed 20 more copies than the 700 and had them in portfolio, I have told him to deliver them to Mr. Coquebert's who had paid him for the paper and the printing.", Archives de l'Académie royale de Belgique, $\mathrm{n}^{\circ}$ 8864, Scientific correspondence of J.J. Omalius d'Halloy, Letter from Del Marmot de Saint Marc to J.J. Omalius d'Halloy, February 17, 1823, fol. 472. 
project of publishing a "Mineralogical and agricultural map of France following the information collected by..." 76 Two distinct cartographic projects had actually been imagined following this collaboration: one succeeded, and the other not.

The two men's correspondence between 1821 and 1823 fails to explain the existence of these two parallel projects. Was it Coquebert de Montbret's suggestion which led Omalius d'Halloy to take steps to publish "his" work? Was it their diverging perspective which explains the realization of two different maps? While it is difficult to choose between these two hypothesis, one can however recall Coquebert de Montbret's requests to Omalius d'Halloy to determine the title and fix the key. As early as December 13, 1821, he wrote to Omalius d'Halloy:

"At any rate, I wish that you would send me a very short, yet very precise, note on the geological value you attached to some of the colours you have used to characterize different terrains, above all concerning the Alpine terrain and the terrain of the Jura on whose nature we do not really agree, and also regarding the terrain marked in blue which comprises an association of minerals of quite diverse nature, the point is not to start geological discussions which you may not wish to engage (unfortunately), but to determine what the colours must stand for; please do not forget either to say what, in your opinion, distinguishes the limestone of the Lorraine which you have put in slightly dark yellow from the limestone of the Jura."

In the undated draft of his reply, which Omalius d'Halloy clearly intended for Charles-

Etienne Coquebert de Montbret, he said he was not in a position to answer his request:

"But there is another point on which I cannot at the moment comply with your desire, and this concerns your request for a precise note on the geological value attached to the various colours of the map. I have designed several systems of colouring and I do not remember now which one was used to colour your copy." 78

In addition to his lack of time, Omalius d'Halloy hesitated to disclose work accomplished so many years earlier to a wider public:

"I do not hide from you either that I would have a great reluctance to say something on this matter before seeing what has been done since 1813; this knowledge would prevent the publication of stupidities and confirm the opinions then ventured." ${ }^{79}$

Further on, in the same letter, he added:

"During the winter of 1814, when I was easy between the blade of the cosacks and the cannon of [illegible] I began the writing of a work which would have demanded a lot of time and new journeys on my part. Now I feel I must renounce the idea of finishing it on the scale I had considered, but I [illegible] to renounce the idea of turning it into a kind of excerpt and if my projects are not thwarted, I will go to Paris next July and there endeavour to undertake this task.

\footnotetext{
76 Archives de l'Académie royale de Belgique, ${ }^{\circ}$ 8864, Scientific correspondence of J.J. Omalius d'Halloy, Letter from Charles-Etienne Coquebert de Montbret to J.J. Omalius d'Halloy, March 14, 1823, fol. 278-279.

77 Archives de l'Académie royale de Belgique, ${ }^{\circ}$ 8864, Scientific correspondence of J.J. Omalius d'Halloy, Letter from Charles-Etienne Coquebert de Montbret to J.J. Omalius d'Halloy, December 13, 1821, fol. 268-271.

${ }^{78}$ Archives de l'Académie royale de Belgique, $n^{\circ}$ 8864, Scientific correspondence of J.J. Omalius d'Halloy, Undated draft of a letter from J.J. Omalius d'Halloy clearly to be sent to Charles-Etienne Coquebert de Montbret, in reply of his letter of December 13, 1821, fol. 272-273.

${ }^{79}$ Idem.
} 
My aim was to report [illegible] on the different terrains which are to be found in France, in the Netherlands and in the neighbouring regions. I shall probably be forced to introduce this sketch with a few statements about how I understand the formations and if my masters think this worthwhile, I could add a few excerpts from my diaries. Such is the lack of pretention to which I may devote myself while waiting for the turn of events which will allow me to return to the career out of which I have been pulled by my travellings." 80

Contrary to what this letter may suggest, Omalius d'Halloy did not reject Coquebert de Montbret's propositions; but he reappropriated them in an entirely different, more strictly scientific, perspective, and it was probably at that time that he got in touch with the Annales des mines to publish his “Observations sur un essai de carte géologique...”. Omalius d'Halloy saw this as a means to ensure the intellectual legitimacy of his work. ${ }^{81}$ As early as 1808 , in his Essai sur la géologie du Nord de la France, he had strongly emphasized the difference between geology and statistics:

"Besides, my aim is not to give an idea of the different terrains which constitute the northern parts of France, and I hope one remembers that I am not undertaking a mineralogical statistics, nor a general description of the economic production of these regions; it is in the Memoirs already published or which will be published by Messrs. the Mining Engineers that one will find satisfying details in this regard." ${ }^{, 2}$

In 1822, at the beginning of his Observations, he again addressed the question of the cartographic impact of these differences and proposed a definition of a geological map and of a mineralogical map:

"Two main perspectives seem equally to lead to the division of a country in physical regions determined by the nature of the soil: the first one considers it geologically, i.e. by period of formation; the other only considers it in relation to its mineralogical or rather chemical nature. It might appear that this last means is the one which best reaches the aim, since it seems more related to the action some terrains exert on the vegetation; but, from the other perspective, the different states of aggregation of the substances which compose the terrain, the physical position of the soil, and other circumstances related to the periods of formation, often exert just as marked an influence. The pasture lands of the Pennine Alps, the garrigues of the Languedoc and the fields of the Beauce thus present great differences of aspects and production, although the terrain in each case is of a calcareous nature. One easily perceives that the geological point of view is much more advantageous to the progress of science, that it offers much more interest to the general curiosity, and that, depending on the circumstances, the possibility it offers of reuniting several systems in a single group allows far better to dispense of the detailed observations which would be required in the opposite case by the very frequent changes of the present nature of the dominant substances in a terrain formed during a same period." 83

\footnotetext{
${ }^{80}$ Idem.

${ }^{81}$ According to the letters sent to him by his emissary in Paris, it seems that Omalius d'Halloy caused difficulties giving to the Mining commission the copperplate engraved by Berthe. He eventually complied with this request since his map figures in the scholarly journal with his memoir. However, he did not renounce publishing it, accompanied by his memoir, of which 200 copies were printed. The entire project appeared in February 1823. "The third is a difficulty raised by Mr. Trémery who asks that the copperplate be given to him, he says that it is the intention of the mining commission, that they have the plates of all the works published in their journals and that your memoir would be the only one which would not be accompanied by its plate; he promises to print for you as many copies as you want, yet if you persisted in your intention to keep it, it would be given to me, please let me know what I am to do in this regard.”, Archives de l'Académie royale de Belgique, n 8864, Scientific correspondence of J.J. Omalius d'Halloy, Letter from Del Marmol de Saint Marc to J.J. Omalius d'Halloy, December 29, 1822, fol. 468.

${ }^{82}$ Omalius d'Halloy (Jean-Baptiste Julien d'), Essai sur la géologie du Nord de la France, op. cit., p. 3.

${ }^{83}$ Omalius d'Halloy (Jean-Baptiste Julien d'), Observations..., op.cit., p. 5-6.
} 
Omalius d'Halloy quite obviously chose the geological map, and retained six categories for the map we can consider as "his". He distinguished the primary terrains (Hercynian base, Alps, Pyrenees), Peneans (Permian), Ammoneans (Jurassic, Trias), Cretacy, Mastozootic (Tertiary and Quaternary presumed marine), and Pyroids. More generally, when comparing the drafts to the published map, the effort to synthesize appears quite striking, between the data collected in the course of journeys and the mapping of the main types of terrains. On the one hand, from the draft entitled "Essai de carte géologique de l'Empire français" to the published map, one observes an evolution from 11 to 6 different types of terrains, the designations being only progressively established. On the other hand, the mapping of the Puy de Dôme clearly shows the relationship between the two maps, even if the concern for exhaustivity shown by the density of information consigned on the draft strongly contrasts with the synthetic ambition of the map. The ambition clearly was to turn geological maps into true heuristic tools, or to borrow Ami Boué's words in 1835: to make them "what synoptic charts are for sciences." 84

For Coquebert de Montbret, the map was a tool allowing him to organize spatially data accumulated during investigation. For Omalius d'Halloy, however, the map had to synthesize these elements. The data collected in the field constituted a starting point to construct a nomenclature, whose aim was to render intelligible ill-assorted materials. Once the categories of this nomenclature were established, they were mapped. Here the map was not a tool for localization, but became an indispensable tool for the production of geological knowledge. Coquebert de Montbret appears on the contrary as an heir of the mineralogical maps which primarily represented localized symbolic signs, even if he strove to go beyond these practices in order to locate homogeneous areas. In spite of his knowledge of geognostic maps and his familiarity with geological maps, his own practice as a cartographer remained anchored in a more empiric approach to cartography: he considered the map primarily as a means of representing the visible. Omalius d'Halloy, however, sought to go beyond the visible to reach the intelligible: he intended to map the stages of the progressive formation of the globe and tried to articulate the local data stemming from observations with a unifying conceptual vision. This capacity to create models seems indeed quite foreign to the practice of Coquebert de Montbret, whose efforts were more concerned with reduction and generalization, while Omalius d'Halloy was quite explicitly making attemps to create models. ${ }^{85}$

\footnotetext{
${ }^{84}$ Boué (Ami), op. cit., p. 142.

85 "It has thus been necessary to sacrifice to uniformity the so natural desire to present all the details we had in our possession on certain regions, albeit keeping the possibility to reproduce them in specific memoirs; we also
} 
This difference of perspectives, however, by no means hindered the relations between the two men, Coquebert de Montbret on the contrary seemed concerned to make the work of Omalius d'Halloy as well known as possible. In 1823, he suggested he have his map reprinted:

"I have long disposed of the copies of your map and memoir as you desired, don't you think it would be relevant to have your text reprinted and to have it sold with the map. In this way more people would have this work in their hands." 86

A letter from Del Marmol de Saint Marc also shows Coquebert de Montbret's interest in making Omalius d'Halloy's work known:

"Your work, your map have a great impact among geologists and among the English who regret being unable to buy it. Mr. Coquebert entrusted me with telling you he would advise you to have a few more copies of it printed and to put them up for sale in a few bookshops, V. Huzard's or others; he knows you are not interested in the profit of the thing, but different amateurs would buy it and he suggests this for the progress of geological science." 87

Was it to comply with these requests that Omalius d'Halloy published his map again ? He did not offer any explanations. At any rate, in 1828, he published in Namur some Mémoires pour servir à la description géologique des Pays-Bas, de la France et de quelques contrées voisines. This volume contained a map entitled "Essai d'une carte géologique des Pays-Bas et de quelques contrées voisines par JJ. d'Omalius d'Halloy": this time Coquebert de Montbret was not mentioned. However, except for the modifications in the title, the map was strictly identical to the one published in $1822 / 1823{ }^{88}$

\section{Conclusion}

Although the Essai d'une carte géologique de la France... does not hold a major place in the history of geological cartography, it has nevertheless given rise to quite laudatory

have had to imagine a system which, while disregarding a great many of the divisions established by the authors, still conserved the most crucial sections, and was in relation with the manifestation of the various terrains in the regions I wanted to represent: one will easily conceive that if specific terrains are often so narrow that their existence cannot be indicated separately on the map, and that, moreover, certain terrains have general relations which distinguish them from the other groups, it will be best to represent them by a common sign, rather than undertaking a distinction which can only be true in a small number of cases.", Omalius d'Halloy (Jean-Baptiste Julien d'), Observations..., op.cit., p. 4-5.

${ }^{86}$ Archives de l'Académie royale de Belgique, $\mathrm{n}^{\circ}$ 8864, Scientific correspondence of J.J. Omalius d'Halloy, Letter from Charles-Etienne Coquebert de Montbret to J.J. Omalius d'Halloy, March 14, 1823, fol. 278-279.

${ }^{87}$ Archives de l'Académie royale de Belgique, $\mathrm{n}^{\circ}$ 8864, Scientific correspondence of J.J. Omalius d'Halloy, Letter from Del Marmol de Saint Marc to J.J. Omalius d'Halloy, February 17, 1823, fol. 472 ; in June 1826, Del Marmol de Saint Marc insisted, adding: "This work is quite in demand here, people write to Paris to get it, and one cannot obtain it even for a fortune; the students of the Ecole des mines moan about this and science suffers. Wouldn't it be possible to urge the author to part for a short time with the copperplate of this map, which may be relegated to a dusty nook, to bring to light a few copies of it here." Archives de l'Académie royale de Belgique, $\mathrm{n}^{\circ}$ 8864, Scientific correspondence of J.J. Omalius d'Halloy, Letter from Del Marmol de Saint Marc to J.J. Omalius d'Halloy, June 20, 1826, fol. 480.

${ }^{88}$ Omalius d'Halloy (Jean-Baptiste Julien), Mémoires pour servir à la description géologique des Pays-Bas de la France et de quelques contrées voisines, Namur, Imprimerie de D. Gérard, 1828. 
commentaries from François Ellenberger for whom it achieved "great clarity by its grouping of all the terrains into six major terrains". He added:

"However humble in comparison with the splendid British accomplishments of the period, the 1822 map of Omalius d'Halloy represents an important landmark in the history of cartography, itself a reflection of the history of European stratigraphy." ${ }^{89}$

More recently, Pierre Savaton has also resituated this map in the history of the geological cartography of France :

"By its outlines and by the effects of colours, one already sees the great geological units visible on a modern geological map of France. This map is much more modern than that of Cuvier and Brongniart; it maps terrains designated by a name related to their age and not by their sole lithological nature. It also suppresses the 'blanks', and expresses a global discourse, it attempts to synthesize a little more.",90

However, beyond its importance in the history of geology, there are other reasons to study this map. The context of its production shows the interaction between scholarly and administrative knowledge; the existent archives allow us today to grasp how the map was constructed, from sketches to publication, and to perceive the divergences between the two protagonists. Here the map clearly emerges as a site where learning was constituted. Finally, this example encourages us to apply Michel Foucault's question - "what is an author ?"- to the history of cartography. The collaboration between Omalius d'Halloy and Coquebert de Montbret suggests the complexity of the answer, which a study of similar collaborations would only reinforce.

(Translated from French by Céline Grasser)

\footnotetext{
${ }^{89}$ Ellenberger (François), op.cit., p. 45.

${ }^{90}$ Savaton (Pierre), "Evolution des cartes géologiques...”, op. cit., p. 66.
} 
Bibliography:

Bourguet (Marie-Noëlle), Déchiffrer la France : la statistique départementale à l'époque napoléonienne, Paris, Editions des archives contemporaines, 1989.

Cook (Karen Severud), "From False Starts to Firm Beginnings : Early Colour Printing of Geological Maps", Imago Mundi, n 47, 1995, p. 155-172.

Cooper (Alix), “'The Possibilities of the Land' : The Inventory of 'Natural Riches' in the Early Modern German Territories", Annual Supplement to Volume 35 History of Political Economy, edited by Margaret Schabas and Neil de Marchi, Duke University Press, Durham and London, 2003, p. 129-153.

Dudich (E.) éd., Contributions to the History of Geological Mapping. Proceedings of the Xth INHIGEO Symposium, August 16-22 1982, Budapest, Budapest, Akademiai Kiado, 1984.

Ehrenberg (R.E.), "Developments in Cartography and Printing influencing the Publication of Geological Maps", unpublished paper, presented at the U.S. Geological Survey International Centennial Symposium, October 14-19, 1979, Reston, Virginia.

F. Ellenberger, "Recherches et réflexions sur la naissance de la cartographie géologique, en Europe et plus particulièrement en France", Histoire et nature, n' $22-23,1983$, p. 3-54.

Eyles (V.A.), "Mineralogische Karten als Vorläufer moderner geologischer Karten [text in English]", Geologie, 20, 1971, p. 362-366.

Eyles (V.A.), "Mineralogical maps as forerunners of modern geological maps", Cartographical Journal, 9, 1972, p. 133-135.

Gillispie (Charles Coulston), "Omalius d'Halloy”, Dictionary of Scientific Biography, Vol. X, New York, Charles Scribner's Sons, 1974.

Ireland (H.A.), "History of the development of geological maps", Bulletin of the Geological Society of America, 54, 1943, p. 1227-1280.

Konvitz (Josef), Cartography in France 1660-1848. Science, Engineering and Statecraft, Chicago, The University of Chicago Press, 1987.

Laboulais (Isabelle), "Reading a vision of space: The geographical map collection of Charles-Etienne Coquebert de Montbret (1755-1831)", Imago Mundi, volume 56, Part 1, January 2004, p. 48-66.

Lemoine-Isabeau (Claire), La cartographie du territoire belge de 1780 à 1830, entre Ferraris et le Dépôt de la Guerre de Belgique, Brussels, Musée royal de l'armée, 1997, 391 p.

Rappaport (Rhoda), "Problems and sources in the history of Geology, 1749-1810", History of Science, vol. 3, 1964, p. 60-78.

Rudwick (M.J.S.), "The emergence of a visual language for geological science 1760-1840", History of Science, 14, 1976, p. 149-195.

Rudwick (M.J.S.), The New Science of Geology. Studies in the Earth Sciences in the Age of Revolution, Aldershot: Ashgate, 2004.

Pierre Savaton, "Evolution des cartes géologiques de la France depuis le début du XIXe siècle", Géologie de la France, 1999, n² 2, 1999, p. 65-78.

Schneer (C.J.) éd., Towards a History of Geology, Cambridge, Massachusets Institute of Technology Press, 1969.

Torrens (Hugh), The Practice of British Geology 1750-1850, London, Aldershot: Ashgate, 2002, 356 p. 